\title{
The effect of dent versus flint maize genotype on site and the extent of starch and protein digestion, ruminal fermentation and microbial protein synthesis in the rumen of sheep
}

\author{
Jože VERBIČ, Drago BABNIK, Vida ŽNIDARŠIČ-PONGRAC, \\ Mojca RESNIK, Ana GREGORČIČ, Veronika KMECL
}

Agricultural Institute of Slovenia, Hacquetova 17, 1000 Ljubljana, Slovenia

(Received 12 February 2004; accepted 22 July 2005)

\begin{abstract}
Ruminal and whole tract digestibility of protein and starch, microbial protein yield in the rumen and molar proportions of volatile fatty acids (VFA) in the rumen fluid and faeces were determined in sheep that were given either maize silage derived from the dent (DTS) or flint type hybrid (FTS). Degradabilities in the rumen were determined by means of the in sacco method using three sheep and microbial protein yield in the rumen by means of urinary purine derivative excretion using four sheep. The extent of starch and protein degradation was significantly $(P<0.001)$ lower in FTS than in DTS (718 vs. 913 and 704 vs. $767 \mathrm{~g} \cdot \mathrm{kg}^{-1}$ respectively). Differences in whole tract starch and protein digestibility were small ( 986 vs. $997, P<0.01$ and 939 vs. $931 \mathrm{~g} \cdot \mathrm{kg}^{-1}, P<0.05$ in FTS and DTS respectively). The concentration of VFA in the rumen fluid was not affected by the type of silage ( 94.5 and $94.7 \mathrm{mmol} \cdot \mathrm{L}^{-1}$ ); however, FTS induced a higher molar proportion of propionate $(22.6 \%$ vs. $20.7 \%, P<0.05)$ than DTS. The proportion of butyrate was higher in DTS $(13.5 \%$ vs. $10.8 \%, P<0.05)$. Microbial protein supply in FTS was significantly higher than in DTS (109.7 vs. $96.0 \mathrm{~g} \cdot \mathrm{kg}^{-1} \mathrm{DM}$ intake, $\left.P<0.05\right)$. When expressed in relation to fermentable organic matter (FOM) intake, the differences between hybrids were greater (215.6 vs. $158.6 \mathrm{~g}$ of microbial protein per $\mathrm{kg}$ FOM, $P<0.01)$. Lower efficiency of microbial protein synthesis in DTS was probably due to a lower $\mathrm{pH}$ value of rumen liquor $(6.21$ vs. $6.33, P<0.05)$. FTS offered better conditions for the degradation of the fibre fraction in the rumen than DTS. The faeces of sheep that were given FTS contained less DM (304 vs. $\left.371 \mathrm{~g} \cdot \mathrm{kg}^{-1}, P<0.05\right)$ and tended to have a higher concentration of VFA (383 and $\left.235 \mathrm{mmol} \cdot \mathrm{kg}^{-1} \mathrm{DM}, P<0.1\right)$ indicating that in FTS at least one part of the starch which escaped digestion in the rumen passed through the small intestine undigested and was fermented in the large intestine. It was concluded that FTS could provide about three times more postruminally digested starch and about $20 \%$ more metabolisable protein than DTS.
\end{abstract}

maize silage / starch digestion / protein digestion / microbial protein / sheep

\footnotetext{
*Corresponding author: joze.verbic@kis.si
} 
Résumé - Effet du génotype de maïs (denté vs. corné) sur le site et le volume de la digestion de l'amidon et des protéines, sur la fermentation ruminale, et sur la synthèse des protéines microbiennes dans le rumen chez les ovins. La digestibilité des protéines, de l'amidon et des constituants pariétaux dans l'ensemble du tractus digestif, le rendement de synthèse des protéines microbiennes dans le rumen et les proportions molaires des acides gras volatils (AGV) dans le jus de rumen et dans les fèces ont été déterminées sur des ovins qui ont reçu de l'ensilage de maïs de type denté (DTS) ou corné (FTS). Les dégradabilités dans le rumen ont été mesurées par la méthode in sacco sur trois ovins alors que le rendement de synthèse des protéines microbiennes a été déterminé à partir de l'excrétion urinaire des dérivés de purines en utilisant quatre ovins. L'importance de la dégradation de l'amidon et des protéines a été significativement $(P<0,001)$ plus faible pour FTS que pour DTS (respectivement, 718 vs. 913 et 704 vs. $767 \mathrm{~g} \cdot \mathrm{kg}^{-1}$ ). Les différences entre les digestibilités de l'amidon et des protéines dans l'ensemble du tractus digestif ont été faibles (respectivement, 986 vs. $997 \mathrm{~g} \cdot \mathrm{kg}^{-1}, P<0,01$ et 939 vs. $931 \mathrm{~g} \cdot \mathrm{kg}^{-1}, P<0,05$ pour FTS et DTS). La concentration en AGV totaux dans le jus de rumen n'a pas été affectée par le type d'ensilage $\left(94,5\right.$ et $\left.94,7 \mathrm{mmol} \cdot \mathrm{L}^{-1}\right)$, pourtant, FTS a induit des proportions molaires plus élevées de propionate $(22,6$ vs. $20,7 \%, P<0,05)$ et DTS des proportions de butyrate supérieures $(13,5$ vs. $10,8 \%, P<0,05)$. La synthèse des protéines microbiennes pour FTS a été significativement plus élevée que pour DTS $\left(109,7 \mathrm{vs} .96,0 \mathrm{~g} \cdot \mathrm{kg}^{-1} \mathrm{de}\right.$ MS ingérée, $P<0,05)$. Quand elles sont exprimées par rapport à l'ingestion de la matière organique fermentescible (MOF), les différences entre les hybrides sont plus importantes $(215,6$ vs. $158,6 \mathrm{~g}$ de protéines microbiennes par kg MOF, $P<0,01$ ). L'efficacité plus faible de la synthèse de protéines microbiennes pour DTS est probablement due à la valeur plus faible du $\mathrm{pH}$ ruminal $(6,21$ vs. 6,33 , $P<0,05)$. Les FTS ont présenté les conditions les plus favorables pour la dégradation de la fraction fibreuse dans le rumen. Les fèces des ovins qui ont reçu FTS étaient moins riches en MS (304 vs. $\left.371 \mathrm{~g} \cdot \mathrm{kg}^{-1}, P<0,05\right)$ et tendaient à être plus riche en AGV $\left(383\right.$ et $\left.235 \mathrm{mmol} \cdot \mathrm{kg}^{-1} \mathrm{DM}, P<0,1\right)$; ce qui laisse supposer que, pour FTS, une partie de l'amidon, non dégradé dans le rumen, n'a pas été digéré dans l'intestin grêle et a été fermenté dans le gros intestin. En conclusion, FTS semble fournir approximativement trois fois plus d'amidon digéré dans l'intestin et $20 \%$ de protéines métabolisables en plus que DTS.

ensilage de maïs / digestion de l'amidon / digestion de la protéine / protéine microbienne / ovins

\section{INTRODUCTION}

Maize silage is an important component of winter diets for cattle. In many countries the estimated production of maize silage exceeds that of grass silage [50]. In several European countries, special approval schemes for hybrids suitable for silage production have been developed [3]. Besides dry matter yields, the quality criteria has become an important factor which is taken into account in such approval schemes. Quality is usually assessed on the basis of in vitro organic matter digestibility. In comparison to stover, organic matter digestibility of ears is relatively high but considerably less variable [8]. Therefore, it is not surprising that until now relatively little attention was paid to the quality of the grain. However, there are some data indicating that, despite relatively constant whole tract digestibility, maize hybrids can vary widely as to the site of grain digestion. Flachowsky et al. [16] reported that dry matter degradability of the maize grain after six-hour incubation in the rumen varied between $35.2 \%$ and $56.9 \%$. A few years later, differences between hybrids were attributed to the type of grain, with the dent grain being degraded in the rumen more extensively than the flint type $[35,49]$. Shifting starch digestion from the rumen to the small intestine may have potential benefits, although the available information is not consistent. Based on a review of experiments with growing cattle, Owens et al. [31] reported that starch digested in the small intestine provides about $40 \%$ more energy to the animal than starch digested in the rumen. On the contrary, in experiments with dairy cows there was no evidence to show a benefit of shifting starch digestion from the 
rumen to the intestine $[30,39]$. In the case of manipulating the ruminal starch digestion of dried grains by the means of less intensive processing, milk production can even be decreased [45]. Knowlton et al. [23] reported that starch infused to the abomasum of early lactating cows resulted in a better glucose supply than starch infused to the rumen. However, several studies indicate that in usual diets, the reduction of starch digestion in the rumen increases the large intestinal fermentation [22, 27] and decreases starch total tract digestibility [22, $27,39,45]$. It is likely that the reasonableness of manipulating starch digestion in ruminants depends on the type of the diet. Since the ensiling process increases starch degradability in the rumen [36], manipulation of starch degradability in maize silage may be of greater importance than in dried maize grain.

Philippeau et al. [38] reported that variation in ruminal starch degradation of maize grains was closely related to the protein distribution in the endosperm. It is surprising that, to our knowledge, there are no reports in the literature on the variability among hybrids in ruminal degradability of protein. The reason may lie in a relatively low protein concentration in maize silage, which makes the research in this field unattractive. However, in regions where the conditions for maize growing are favourable, maize silage is included in diets for cattle in such quantities that protein derived from it cannot be neglected. Besides protein per se, maize silage provides a considerable amount of energy for microbial protein synthesis in the rumen. The Dutch protein system [44] takes into account the fact that starch which escapes degradation in the rumen does not supply any energy for microbial protein synthesis. Therefore, lower microbial protein yield may be expected in diets containing silages made from hybrids which are characterised by low starch degradability in the rumen.

Studies reporting variability among hybrids in ruminal degradability of starch were done mainly on dried and ground samples of maize grain. Since it has been shown that degradability of starch in the rumen is affected by drying [25], grinding [36] and ensiling [36], we decided to design a study on undried, unground maize silage samples. The purpose of this work was also to examine whether the possible differences in degradation of starch affected ruminal $\mathrm{pH}$ value, ruminal fermentation pattern, digestion of non-grain parts of maize and microbial protein yield in the rumen. Protein degradability was also examined.

\section{MATERIALS AND METHODS}

\subsection{Materials}

Two maize hybrids differing in their endosperm texture were sown in alternate row arrangement at maize population density of 94700 plants per ha. Maize was harvested with a precision-chop harvester with a theoretical chop length of $6.5 \mathrm{~mm}$ and ensiled in 6 experimental silos containing $0.785 \mathrm{~m}^{3}$ of silage each. The silages were prepared within the same day. Fifteen plants of each hybrid from the same experiment were also harvested for determination of the degradation of the non-grain part fraction of forage maize in the rumen. The plants were separated into five fractions consisting of stalks, leaves, husks, cobs and grain, dried at $60{ }^{\circ} \mathrm{C}$ and ground through a $5 \mathrm{~mm}$ screen in a laboratory hammer mill.

\subsection{Rumen study}

\subsubsection{Animals and feeding}

Three adult Jezersko-Solčavska sheep $(74.3 \pm 1.2 \mathrm{~kg})$, each fitted with a ruminal cannula, were used. During a three week pre-experimental period they were gradually adapted to experimental diets. The sheep were kept in individual pens and had free access to water. During the experiment, they were offered $3200 \mathrm{~g}$ (1180 g DM) of 
dent type hybrid silage (DTS) or $3100 \mathrm{~g}$ (1160 g DM) of flint type hybrid silage (FTS) per day in the first and second period respectively. Each period lasted for 29 days. The diets were given to animals in two equal portions at $6.30 \mathrm{a} . \mathrm{m}$. and $6.30 \mathrm{p} . \mathrm{m}$. They were supplemented with urea (14.8 g $\mathrm{N} \cdot \mathrm{day}^{-1}$ ) and mineral vitamin mix which provided $3.95 \mathrm{~g} \mathrm{Ca}, 0.73 \mathrm{~g} \mathrm{P}, 1.35 \mathrm{~g} \mathrm{Na}$, $1.62 \mathrm{~g} \mathrm{~S}, 140 \mathrm{mg} \mathrm{Mn}, 40 \mathrm{mg} \mathrm{Zn}, 0.24 \mathrm{mg} \mathrm{J}$ and $0.12 \mathrm{mg} \mathrm{Se}, 300$ i.u. $\mathrm{D}_{3}$ and 3000 i.u. vitamin A per sheep per day. Together with minerals and vitamins from silages, the mineral vitamin mix should cover both the needs of the animals $[1,2]$ as well as the needs of rumen microorganisms [13].

\subsubsection{In situ measurements}

The degradabilities of starch and protein were determined by the in sacco method as described by Ørskov et al. [34]. About $11 \mathrm{~g}$ of fresh silage sample which was equivalent to about $4 \mathrm{~g} \mathrm{DM}$ were weighed into nylon bags with an internal size of $100 \times 75 \mathrm{~mm}$ and stored at $-20{ }^{\circ} \mathrm{C}$ before incubation in the rumen. The bags were made from nylon filter cloth LT 075 (Locker Wire Weawers, Warrington, England) with a pore size of 45-55 $\mu \mathrm{m}$. Average sample size to bag surface ratio was $27 \mathrm{mg} \mathrm{DM} \cdot \mathrm{cm}^{-2}$. Bags in triplicates were introduced into the rumen of each sheep $1.5 \mathrm{~h}$ after feeding and removed after $3,6,12,24,48$, and $72 \mathrm{~h}$ of incubation. All incubations were repeated twice during the days 21 to 28 of each experimental period. Eighteen measurements were made for each incubation time (three sheep $\times$ three replicates $\times$ two time repetitions). After removal from the rumen, the bags were first thoroughly rinsed under running tap water and then washed in a domestic washing machine (4 rinses $\times 3 \mathrm{~min}$ and 1 rinse $\times 5 \mathrm{~min}$ ). The bags with undegraded samples were then dried at $60^{\circ} \mathrm{C}$ and weighed. Undegraded residues were ground and homogenised in a laboratory mill and then analysed for ash, crude protein and starch. The whole procedure was repeated twice, first in the rumen of sheep that were given DTS (first experimental period) and then in the rumen of sheep that were given FTS (second experimental period).

Starch and protein losses from the bags were expressed as proportions of individual compounds which disappeared from nylon bags during the incubation in the rumen. Washing losses of starch and the protein fraction $\left(A_{S}\right.$ and $\left.A_{P}\right)$ were determined by soaking the bags with samples in hot water $\left(39^{\circ} \mathrm{C}\right)$ for 1 hour. Then they were washed as described previously. Data on starch and protein losses from the bags at different incubation times $(\mathrm{t})$ were fitted to the equation $\mathrm{p}=\mathrm{a}+\mathrm{b}\left(1-\mathrm{e}^{-\mathrm{ct}}\right)$ where coefficient $\mathrm{a}$ represents the rapidly degradable fraction, coefficient $b$ the slowly degradable fraction and coefficient $\mathrm{c}$ the degradation rate of fraction $b$ [32]. The coefficients of the exponential equation $(a, b, c)$ were obtained with the aid of STATGRAPHICS PLUS computer program [41] using a non-linear regression procedure. The potential degradabilities of starch and protein $\left(\mathrm{PDG}_{\mathrm{S}}\right.$ and $\left.\mathrm{PDG}_{\mathrm{P}}\right)$ were defined as $(\mathrm{a}+\mathrm{b})$. Effective degradabilities $\left(\mathrm{EDG}_{\mathrm{S}}\right.$ and $\left.\mathrm{EDG}_{\mathrm{P}}\right)$ were calculated as EDG $=a+\frac{b c}{c+k}$ [32]. The measured rumen outflow rate $(\mathrm{k})$ was used in the calculations. It was not affected by the type of silage and averaged $\mathrm{k}=0.043 \mathrm{~h}^{-1}$.

Conditions for cellulolysis in the rumen of sheep given either FTS or DTS were tested by incubating samples of non-grain parts of both hybrids in the rumen. Samples of stalks, leaves, husks and cobs were pooled taking into account their proportions in DM yields and incubated in the rumen using a similar procedure as described previously. About $3 \mathrm{~g}$ of sample were weighed into nylon bags and incubated in the rumen for 24 hours. Measurements in 6 repetitions ( 6 bags per sample and sheep) were done on day 29 of each experimental period.

\subsubsection{Rumen fluid measurements}

About $60 \mathrm{~mL}$ of rumen fluid was withdrawn through the rumen cannula just 
before and 2, 4, 6, 8 and $12 \mathrm{~h}$ after the morning feeding on days 18 and 19 of each experimental period. Within 3 minutes after withdrawal from the rumen, the $\mathrm{pH}$ value of the fluid was measured. After centrifugation at $1250 \times g$, the supernatant was acidified with concentrated $\mathrm{H}_{2} \mathrm{SO}_{4}$ to give a final $\mathrm{pH}<4$ and stored frozen until volatile fatty acids and ammonia determinations.

\subsection{In vivo study}

\subsubsection{Animals and feeding}

Four Jezersko-Solčavska sheep weighing $57.3 \mathrm{~kg}$ on average (SEM $1.9 \mathrm{~kg}$ ) were used. They were adapted to diets containing urea supplemented maize silage during the three week pre-experimental period. During the experiment, the animals were kept in metabolism cages with free access to fresh water. Each silage was offered to each sheep for 28 days using a cross-over design. They were given $3750 \mathrm{~g}$ (1335 g DM) of DTS or $3530 \mathrm{~g}$ (1300 $\mathrm{g} \mathrm{DM})$ of FTS per day. The diets were formulated to contain equal amounts of DM and were given in two equal portions at 07.00 and 19.00. They were supplemented with urea (16.4 g N.day ${ }^{-1}$ ) and the same amount of mineral vitamin mix as in the rumen study.

\subsubsection{Measurement of digestibility, microbial protein supply and rumen outflow rates}

Digestibility was determined using the total faeces collection method. The faeces were collected daily from days 22-28 and stored at $-20{ }^{\circ} \mathrm{C}$ until the end of the collection period. The samples were then bulked, weighed, sampled and dried at $60{ }^{\circ} \mathrm{C}$ for determination of organic matter, starch, crude protein, neutral detergent fibre (NDF), acid detergent fibre (ADF) and acid detergent insoluble nitrogen (ADIN). In addition, fresh samples for the determination of volatile fatty acids were taken. True protein digestibility was calculated by taking into account the fact that acid detergent insoluble protein was the only truly undigested feed protein fraction which appeared in the faeces [47].

Microbial protein supply was determined on the basis of the urinary purine derivative excretion using the model described by Chen et al. [6, 7]. Urine was collected daily from days $22-28$. The collection was performed under $1 \mathrm{M} \mathrm{H}_{2} \mathrm{SO}_{4}$ to maintain a $\mathrm{pH}$ value below 3 . Daily urine amounts were diluted to $5.5 \mathrm{~L}$, mixed, sampled and stored at $-20{ }^{\circ} \mathrm{C}$. Daily samples were bulked before purine derivative analyses.

The rumen particle outflow rate was determined using $\mathrm{Cr}$-mordanted hay as a marker [46]. Sixty g of Cr-mordanted hay was mixed into a morning diet on d 15 . Faecal samples for determination of $\mathrm{Cr}$ were collected $6,12,18,30,36,48,60,72,84$, 96 and $120 \mathrm{~h}$ after administration of the marker into the diet. The outflow rates were calculated on the basis of $\mathrm{Cr}$ concentrations in faeces using the model G2G1 according to Moore et al. [28].

\subsection{Analytical procedures}

Dry matter of silages was determined by the distillation method as described by Dewar and McDonald [9]. Crude protein was analysed according to the Kjeldahl method [29]. Neutral detergent fibre (NDF), acid detergent fibre (ADF), acid detergent lignin (ADL) and acid detergent insoluble nitrogen (ADIN) were determined according to Goering and Van Soest [17]. Prior to NDF determination, starch was degraded by a heat stable $\alpha$-amylase [48]. Total sugars were determined according to the LuffShoorl method [29]. For determination of starch, an enzymatic method was used [4]. Purine derivatives (allantoin, uric acid, xanthine and hypoxanthine) in urine were analysed by high performance liquid chromatography with the modified method of Diez et al. [11]. Concentrations of $\mathrm{Cr}$ in faecal samples were determined by atomic 
Table I. Chemical composition of maize silages $(n=6)$.

\begin{tabular}{lcccc}
\hline Item & FTS & DTS & SEM & Significance \\
\hline Dry matter $\left(\mathrm{g} \cdot \mathrm{kg}^{-1}\right)$ & 369 & 374 & 3 & NS \\
Crude protein $\left(\mathrm{g} \cdot \mathrm{kg}^{-1} \mathrm{DM}\right)$ & 73 & 74 & 1 & $\mathrm{NS}$ \\
$\mathrm{NDF}\left(\mathrm{g} \cdot \mathrm{kg}^{-1} \mathrm{DM}\right)$ & 349 & 371 & 7 & $<0.1$ \\
$\mathrm{ADF}\left(\mathrm{g} \cdot \mathrm{kg}^{-1} \mathrm{DM}\right)$ & 199 & 206 & 3 & $\mathrm{NS}$ \\
$\mathrm{ADL}\left(\mathrm{g} \cdot \mathrm{kg}^{-1} \mathrm{DM}\right)$ & 27 & 30 & 1 & $\mathrm{NS}$ \\
Starch $\left(\mathrm{g} \cdot \mathrm{kg}^{-1} \mathrm{DM}\right)$ & 344 & 284 & 9 & $<0.1$ \\
Total sugars $\left(\mathrm{g} \cdot \mathrm{kg}^{-1} \mathrm{DM}\right)$ & 10.4 & 12.3 & 2.2 & NS \\
Lactic acid $\left(\mathrm{g} \cdot \mathrm{kg}^{-1} \mathrm{DM}\right)$ & 48.5 & 48.2 & 1.4 & NS \\
Acetic acid $\left(\mathrm{g} \cdot \mathrm{kg}^{-1} \mathrm{DM}\right)$ & 20.6 & 16.5 & 3.5 & NS \\
Butyric acid $\left(\mathrm{g} \cdot \mathrm{kg}^{-1} \mathrm{DM}\right)$ & 0.00 & 0.00 & $/$ & $/$ \\
Propionic acid $\left(\mathrm{g} \cdot \mathrm{kg}^{-1} \mathrm{DM}\right)$ & 0.01 & 0.00 & 0.01 & NS \\
Valeric acid $\left(\mathrm{g} \cdot \mathrm{kg}^{-1} \mathrm{DM}\right)$ & 0.01 & 0.00 & 0.00 & NS \\
\hline
\end{tabular}

FTS: flint type silage, DTS: dent type silage, DM: dry matter, NDF: neutral detergent fibre, ADF: acid detergent fibre, ADL: acid detergent lignin, SEM: standard error of the mean, NS: $P>0.10$.

absorption spectrophotometry on a Perkin Elmer 2380 instrument at $357.9 \mathrm{~nm}$ using a nitrous oxide-acetylene flame. The concentrations of volatile fatty acids in the silage, rumen fluid and faeces were determined using gas chromatography according to Holdemann and Moore [21]. Ammonia concentration in rumen liquid was analysed by an automated photometric technique using the Bran + Luebbe, AA II method (No. G-016-91).

\subsection{Statistical analyses}

Data were subjected to analysis of variance with the aid of STATGRAPHICS PLUS [41]. Data on degradation characteristics of starch, protein and non-grain parts were analysed using the model $\mathrm{Y}_{\mathrm{ijkl}}=\mu+$ $\mathrm{T}_{\mathrm{i}}+\mathrm{D}_{\mathrm{j}}+\mathrm{A}_{\mathrm{k}}+\mathrm{TD}_{\mathrm{ij}}+\mathrm{e}_{\mathrm{ijkl}}$, where $\mathrm{Y}_{\mathrm{ijkl}}=$ dependent variable, $\mu=$ overall mean, $T_{i}=$ direct effect of hybrid ( $i=1$ to 2 ), $D_{j}=$ dietary effect of hybrid ( $\mathrm{j}=1$ to 2$), A_{k}=$ effect of experimental animal $(\mathrm{k}=1$ to 3$), \mathrm{TD}_{\mathrm{ij}}=$ interaction of $\mathrm{T}$ by $\mathrm{D}$, and $\mathrm{e}_{\mathrm{ijkl}}=$ residual error. With an in vivo study (digestibilities, microbial protein supply, outflow rates and nitrogen balance, composition of faeces) only the minor part of total variation was explained by the effect of experimental animal. Therefore, the model was reduced to $Y_{i j}=\mu+T_{i}+e_{i j}$, where $T_{i}=$ effect of grain texture ( $\mathrm{i}=1$ to 2 ), and $\mathrm{e}_{\mathrm{ij}}=$ residual error. Ruminal variables were analysed as repeated measures by the MIXED Model procedure of SAS [42] assuming a compound symmetry variance-covariance structure. The model used was $\mathrm{Y}_{\mathrm{ijkl}}=\mu+\mathrm{T}_{\mathrm{i}}+\mathrm{e}_{\mathrm{ij}}+\mathrm{P}_{\mathrm{k}}+$ $\mathrm{TP}_{\mathrm{ik}}+\mathrm{e}_{\mathrm{ijkl}}$, where $\mathrm{Y}_{\mathrm{ijkl}}=$ dependent variable, $\mu=$ overall mean, $T_{i}=$ effect of hybrid ( $\mathrm{i}=1$ to 2 ), $\mathrm{e}_{\mathrm{ij}}=$ whole plot error, $\mathrm{P}_{\mathrm{k}}=$ effect of time ( $\mathrm{k}=1$ to 6$), \mathrm{TP}_{\mathrm{ik}}=$ interaction of $\mathrm{T}$ and $\mathrm{P}$, and $\mathrm{e}_{\mathrm{ijkl}}=$ repeated subplot error.

\section{RESULTS}

\subsection{Chemical composition}

The chemical composition of silages is presented in Table I. Silages of similar DM concentration were prepared from both hybrids. FTS had higher starch concentration and lower NDF concentration compared to DTS. Higher concentration of starch in FTS was a consequence of a considerably higher proportion of grain in total DM yield $(0.515$ vs. $0.454, P<0.05)$. Silages did not differ significantly in the 
Table II. Effect of maize hybrid on the rate and extent of ruminal starch degradability.

\begin{tabular}{|c|c|c|c|c|c|c|c|c|}
\hline \multirow{2}{*}{$\begin{array}{l}\text { Item } \\
\left(\mathrm{g} \cdot \mathrm{kg}^{-1} \text { or as }\right. \\
\text { stated })\end{array}$} & \multicolumn{2}{|c|}{ Flint type diet } & \multicolumn{2}{|c|}{ Dent type diet } & \multirow[b]{2}{*}{ SEM } & \multicolumn{3}{|c|}{ Significance } \\
\hline & FTS & DTS & FTS & DTS & & Sample & Diet & Sample $\times$ Diet \\
\hline $\mathrm{A}_{\mathrm{S}}$ & 509 & 763 & 509 & 763 & I & I & I & I \\
\hline$a_{S}$ & 382 & 688 & 477 & 718 & 29.6 & 0.001 & 0.10 & NS \\
\hline $\mathrm{b}_{\mathrm{S}}$ & 618 & 307 & 584 & 278 & 33.0 & 0.001 & NS & NS \\
\hline $\mathrm{c}_{\mathrm{S}}\left(\mathrm{h}^{-1}\right)$ & 0.054 & 0.118 & 0.044 & 0.098 & 0.0089 & 0.001 & NS & NS \\
\hline $\mathrm{PDG}_{\mathrm{S}}$ & 1000 & 994 & 1061 & 997 & 30.8 & NS & NS & NS \\
\hline $\mathrm{EDG}_{\mathrm{S}}$ & 718 & 912 & 761 & 913 & 11.6 & 0.001 & NS & NS \\
\hline
\end{tabular}

A: washing loss, a: rapidly degradable fraction, b: slowly degradable fraction, c: degradation rate of slowly degradable fraction, PDG: potential degradability, EDG: effective degradability. For abbreviations see also Table I.

Table III. Effect of maize hybrid on in situ ruminal protein degradation of maize silage.

\begin{tabular}{|c|c|c|c|c|c|c|c|c|}
\hline \multirow{2}{*}{$\begin{array}{l}\text { Item }\left(\mathrm{g} \cdot \mathrm{kg}^{-1} \text { or }\right. \\
\text { as stated })\end{array}$} & \multicolumn{2}{|c|}{ Flint type diet } & \multicolumn{2}{|c|}{ Dent type diet } & \multirow[b]{2}{*}{ SEM } & \multicolumn{3}{|c|}{ Significance } \\
\hline & FTS & DTS & FTS & DTS & & Sample & Diet & Sample $\times$ Diet \\
\hline$A_{P}$ & 581 & 675 & 581 & 675 & I & I & I & / \\
\hline$a_{P}$ & 545 & 633 & 556 & 632 & 16.0 & 0.01 & NS & NS \\
\hline$b_{P}$ & 327 & 236 & 294 & 227 & 13.7 & 0.01 & NS & NS \\
\hline$c_{P}\left(h^{-1}\right)$ & 0.041 & 0.054 & 0.041 & 0.062 & 0.0062 & 0.05 & NS & NS \\
\hline $\mathrm{PDG}_{\mathrm{P}}$ & 872 & 870 & 850 & 859 & 6.8 & NS & 0.10 & NS \\
\hline $\mathrm{EDG}_{\mathrm{P}}$ & 704 & 765 & 698 & 767 & 4.9 & 0.001 & NS & NS \\
\hline
\end{tabular}

For abbreviations see Tables I and II.

concentrations of crude protein, ADF, ADL, fermentation acids and total sugars $(P>0.10)$.

\subsection{Degradability of starch, protein and non-grain parts in the rumen}

Degradation characteristics of starch in the rumen are presented in Table II. Effective starch degradability in FTS was lower than in DTS (740 vs. $912 \mathrm{~g} \cdot \mathrm{kg}^{-1}, P<0.001$ ). Differences in effective starch degradabilities were mainly due to differences in the rapidly degradable fraction a. Across both diets, flint and dent, the FTS sample was also characterised by a lower degradation rate of starch (0.049 vs. $\left.0.108 \mathrm{~h}^{-1}, P<0.01\right)$ than FTS. The diet did not significantly affect the effective starch degradability and sample $\times$ diet interaction was not significant.

Characteristics of protein degradation in the rumen are presented in Table III. Across both diets, flint and dent, FTS had a lower effective protein degradability than DTS (702 vs. $766 \mathrm{~g} \cdot \mathrm{kg}^{-1}, P<0.001$ ). Differences in the effective degradability were due to differences in the rapidly degradable protein fraction $\left(550 \mathrm{vs} .633 \mathrm{~g} \cdot \mathrm{kg}^{-1}, P<0.01\right)$ and to a lower degradation rate (0.041 vs. $\left.0.058 \mathrm{~h}^{-1}, P<0.05\right)$.

Values illustrating the disappearance of the samples of non-grain parts from nylon bags inserted in the rumen are presented in Table IV. Hybrid per se did not affect the degradability of non-grain parts, however, a significant effect due to diet was noted. 
Table IV. Effects of diet and sample on the in situ degradation of non-grain parts of maize plant in the rumen.

\begin{tabular}{|c|c|c|c|c|c|c|c|c|}
\hline \multirow{2}{*}{$\begin{array}{l}\text { Item } \\
\left(\mathrm{g} \cdot \mathrm{kg}^{-1}\right)\end{array}$} & \multicolumn{2}{|c|}{ Flint type diet } & \multicolumn{2}{|c|}{ Dent type diet } & \multirow[b]{2}{*}{ SEM } & \multicolumn{3}{|c|}{ Significance } \\
\hline & FTS & DTS & FTS & DTS & & Sample & Diet & Sample $\times$ Diet \\
\hline $\begin{array}{l}\text { DM degradability } \\
(24 \mathrm{~h})\end{array}$ & 454 & 480 & 393 & 400 & 13.5 & NS & 0.01 & NS \\
\hline
\end{tabular}

For abbreviations see Table I.

Table V. Concentrations of volatile fatty acids (VFA) and ammonia and $\mathrm{pH}$ in the rumen fluid of sheep given diets containing dent or flint type hybrid silage.

\begin{tabular}{lcccc}
\hline Item & FTS & DTS & SEM & Significance \\
\hline Mean rumen pH & 6.33 & 6.21 & 0.06 & 0.05 \\
Ammonia $\left(\mathrm{mg} \cdot \mathrm{L}^{-1}\right)$ & 213 & 236 & 28 & $\mathrm{NS}$ \\
Total VFA (mmol $\cdot \mathrm{L}^{-1}$ ) & 94.5 & 94.7 & 2.4 & $\mathrm{NS}$ \\
Molar proportion of VFAs $(\%)$ & & & & \\
$\quad$ Acetate & 63.3 & 62.7 & 0.64 & $\mathrm{NS}$ \\
$\quad$ Propionate & 22.6 & 20.7 & 0.3 & 0.05 \\
$\quad$ Butyrate & 10.8 & 13.5 & 0.6 & 0.05 \\
Isobutyrate & 0.78 & 0.76 & 0.02 & $\mathrm{NS}$ \\
$\quad$ Valerate & 1.13 & 1.10 & 0.05 & $\mathrm{NS}$ \\
$\quad$ Isovalerate & 1.42 & 1.23 & 0.06 & 0.10 \\
Acetate:Propionate ratio & 2.82 & 3.07 & 0.07 & 0.10 \\
(Acetate + Butyrate):Propionate ratio & 3.30 & 3.73 & 0.08 & 0.10 \\
\hline
\end{tabular}

For abbreviations see Table I.

For both samples, a 24-hour DM degradability of non-grain parts in the FTS diet was higher than in the DTS diet (467 vs. $\left.397 \mathrm{~g} \cdot \mathrm{kg}^{-1}, P<0.01\right)$. Compared to DTS, FTS seemed to have a beneficial effect on conditions for the degradation of fibre in the rumen.

\subsection{Ruminal fermentation}

Ruminal fermentation characteristics are presented in Table V and Figure 1. The mean $\mathrm{pH}$ value was significantly lower in sheep given DTS than in sheep given FTS (6.21 vs. $6.33, P<0.05)$. The diurnal pattern for rumen $\mathrm{pH}$ differed among diets (Fig. 1). The minimal $\mathrm{pH}$ value was similar for both silages, whereas the period during which the rumen $\mathrm{pH}$ was below 6.2 was considerably longer in animals receiving DTS (about $5.8 \mathrm{~h}$ ) than in animals fed with FTS (about $4.5 \mathrm{~h}$ ). The concentrations of ammonia and total VFA in the rumen fluid were not affected by the type of silage (Tab. V). FTS induced a higher molar proportion of propionate while the proportion of butyrate was higher in sheep given DTS $(P<0.05)$. The acetate to propionate ratio and acetate plus butyrate to propionate ratio tended to be lower in FTS than in DTS $(P<0.10$, Tab. V). 


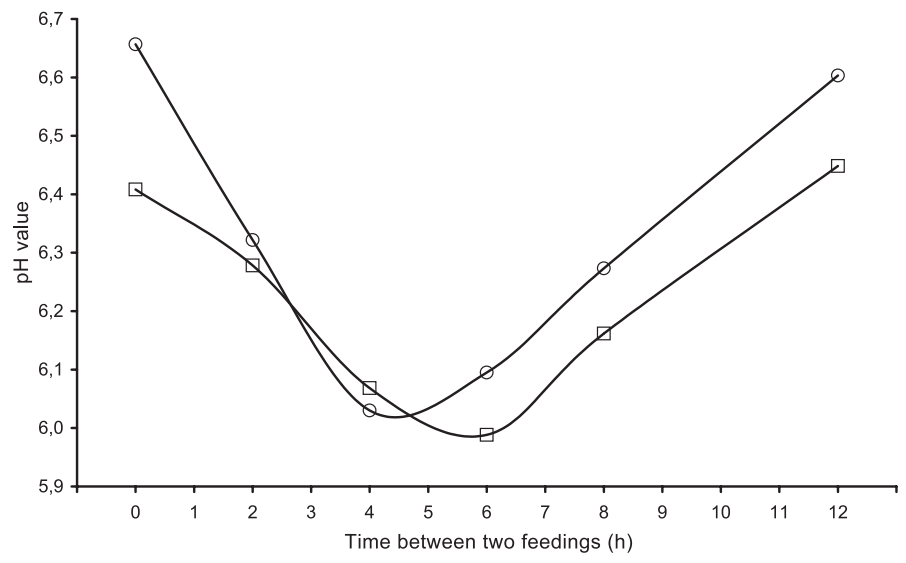

Figure 1. Diurnal variation in the rumen fluid $\mathrm{pH}$ value in sheep which were given flint type (FTS, ○) or dent type (DTS, $\square$ ) silage.

Table VI. Effect of hybrid on rumen outflow rate and digestibility of maize silage in the whole digestive tract of sheep.

\begin{tabular}{lcccc}
\hline Item & FTS & DTS & SEM & Significance \\
\hline Rumen outflow rate $\left(\mathrm{h}^{-1}\right)$ & 0.0438 & 0.0431 & 0.0040 & NS \\
Digestibilities $\left(\mathrm{g} \cdot \mathrm{kg}^{-1}\right)$ & & & & \\
Organic matter (apparent) & 739 & 758 & 5 & 0.05 \\
Organic matter (true) & 897 & 908 & 3 & 0.05 \\
Starch & 986 & 997 & 1 & 0.01 \\
NDF & 536 & 603 & 12 & 0.01 \\
ADF & 522 & 574 & 13 & 0.05 \\
Protein (true) & 939 & 931 & 2 & 0.05 \\
\hline
\end{tabular}

For abbreviations see Table I.

${ }^{a}$ Calculated by taking into account that acid detergent insoluble protein was the only truly undigested feed protein that appeared in the faeces. Value refers only to silage protein, urea supplement was not taken into account in the calculation of digestibility.

\subsection{Total tract digestion of nutrients}

The digestibilities of nutrients in the total digestive tract of sheep are presented in Table VI. In comparison to FTS, DTS had significantly higher digestibilities of organic matter, starch and ADF. In contrast, true protein digestibility was higher in FTS. Although significant $(P<0.05)$, the differences in starch and true protein digestibility were numerically small (11 and $8 \mathrm{~g} \cdot \mathrm{kg}^{-1}$ respectively). The most pronounced differences between silages were observed in the digestibility of ADF.

\subsection{Microbial protein synthesis in the rumen and nitrogen retention}

Microbial protein yield in the rumen was greater for FTS compared to that of DTS (109.7 vs. $96.0 \mathrm{~g} \cdot \mathrm{kg}^{-1} \mathrm{DMI}, P<0.05$, Tab. VII). When expressed in relation to 
Table VII. Effect of hybrid on microbial protein synthesis in the rumen and nitrogen excretion and retention.

\begin{tabular}{|c|c|c|c|c|}
\hline Item & FTS & DTS & SEM & Significance \\
\hline \multicolumn{5}{|c|}{ Microbial protein synthesis $(\mathrm{g} \mathrm{N} \times 6.25)$} \\
\hline per day & 142.4 & 126.6 & 5.4 & 0.10 \\
\hline per kg DMI & 109.7 & 96.0 & 3.8 & 0.05 \\
\hline per kg DOM & 153.5 & 131.6 & 5.4 & 0.05 \\
\hline per kg FOM & 215.6 & 158.6 & 6.9 & 0.01 \\
\hline \multicolumn{5}{|c|}{$\begin{array}{l}\mathrm{N} \text { excretion and retention } \\
\text { (g N per } \mathrm{kg} \mathrm{N} \text { intake) }\end{array}$} \\
\hline excretion in faeces & 240 & 231 & 7 & NS \\
\hline excretion in urine & 614 & 649 & 12 & 0.10 \\
\hline retention & 146 & 120 & 7 & 0.05 \\
\hline
\end{tabular}

DMI: dry matter intake, DOM: digestible organic matter, FOM: fermentable organic matter. For abbreviations see also Table I.

Table VIII. Composition of faeces in sheep offered dent or flint type hybrid silage.

\begin{tabular}{lcccc}
\hline Item & FTS & DTS & SEM & Significance \\
\hline Dry matter $\left(\mathrm{g} \cdot \mathrm{kg}^{-1}\right)$ & 304 & 371 & 17 & 0.05 \\
Total VFA (mmol $\left.\cdot \mathrm{kg}^{-1} \mathrm{DM}\right)$ & 383 & 235 & 48 & 0.10 \\
Molar proportion of VFAs (\%) & & & & \\
$\quad$ Acetate & 84.0 & 84.8 & 1.5 & NS \\
$\quad$ Propionate & 10.9 & 11.3 & 1.1 & NS \\
$\quad$ Butyrate & 2.91 & 2.02 & 0.38 & NS \\
$\quad$ Isobutyrate & 0.84 & 0.82 & 0.08 & NS \\
$\quad$ Valerate & 0.68 & 0.44 & 0.14 & NS \\
$\quad$ Isovalerate & 0.65 & 0.62 & 0.06 & NS \\
\hline
\end{tabular}

For abbreviations see Tables I and V.

digestible or fermentable organic matter intake, the differences between hybrids were even greater (153.5 vs. 131.6 and 215.6 vs. $158.6 \mathrm{~g} \cdot \mathrm{kg}^{-1}$ in FTS and DTS respectively, Tab. VII). In comparison to DTS, FTS also improved nitrogen retention (Tab. VII).

\subsection{Faecal composition}

Relative to sheep fed DTS, the faeces of sheep fed FTS contained less dry matter (304 vs. $371 \mathrm{~g} \cdot \mathrm{kg}^{-1}, P<0.05$, Tab. VIII). The faeces of sheep fed FTS were also characterised by a higher concentration of VFA 
(383 vs. $235 \mathrm{mmol} \cdot \mathrm{kg}^{-1} \mathrm{DM}, P<0.10$ ) indicating more extensive fermentation in the large intestine of sheep given FTS in comparison to sheep given DTS. The type of silage did not affect molar proportions of volatile fatty acids in the faeces (Tab. VIII).

\section{DISCUSSION}

\subsection{Digestion of maize starch and the effect of grain type on rumen fermentation}

The results of the present experiment have indicated a pronounced effect of grain type on ruminal degradability of starch from maize silage (Tab. II). The results are consistent with those of Philippeau and Michalet-Doreau [35] who reported lower starch degradability for ensiled flint maize grain in comparison to dent. Absolute values (740 and $912 \mathrm{~g} \cdot \mathrm{kg}^{-1}$ for FTS and DTS respectively) were higher than those reported for chopped and ensiled flint and dent maize grain by Philippeau and MichaletDoreau [35] (664 and $\left.750 \mathrm{~g} \cdot \mathrm{kg}^{-1}\right)$. The results obtained by the in sacco method depend largely on the method of sample preparation and therefore the results derived from different studies may not be comparable. Degradation of maize starch increases with grinding fineness, which affects first of all the rapidly degradable fraction [35]. An important factor which affects the in sacco results is also drying which leads to a reduction in the degradability of maize starch in the rumen [25]. To eliminate the effect of sample preparation, undried, unground samples of maize silage were used in the present experiment. This may be of special importance since it was found that in maize silage, the distribution of starch in particles of various sizes varied widely between hybrids [15]. The grinding of samples might minimise the differences, which are related to particle size distribution.

Genotype also affected whole tract digestibility of starch which was higher in
DTS (Tab. VI). In agreement with Mills et al. [26], total tract digestion of starch was positively related to its digestion in the rumen. However, in the present experiment the difference in the whole tract digestibility among hybrids was small (997 vs. $\left.986 \mathrm{~g} \cdot \mathrm{kg}^{-1}\right)$ and, although significant, of no practical importance.

The estimated amount of starch digested postruminally was more than three times higher in the flint type hybrid than in the dent (92 vs. $24 \mathrm{~g} \cdot \mathrm{kg}^{-1}$ DM intake, Tab. IX). It should be emphasised that a combination of in vivo and in sacco methods in two separate experiments was used to assess the amount of postruminally digested starch. The latter approach may not give the absolute values; however, we believe that it is suitable for a direct comparison of two feeds.

From the present results, we were not able to locate the postruminal starch digestion. Knowlton et al. [22] reported that by lowering ruminal starch degradability by means of drying (high moisture grain vs. dried grain), starch digestion was shifted to the large intestine. On the contrary, when the extent of starch digestion in the rumen was manipulated by the grain texture it was found that low ruminal digestibility was accompanied by both higher small intestinal and higher large intestinal starch digestion [37]. The faeces of sheep which were given FTS contained less DM and had a higher concentration of VFA (Tab. VIII), indicating that a higher amount of starch was fermented in the colon and caecum [33]. The results of the present study suggest that in the FTS diet, at least one part of starch escaping ruminal fermentation passed through the small intestine undigested and was fermented in the large intestine. Extensive starch fermentation in the large intestine is expected to increase the proportion of butyrate to the detriment of propionate in the faeces [33]. However, it seems that in the present experiment the difference in the amount of starch fermented in the large intestine between diets was not 
Table IX. Effect of maize genotype on the digestion of starch and protein along the digestive tract, microbial protein yield in the rumen and estimated supply of metabolisable protein in sheep ${ }^{\mathrm{a}}$.

\begin{tabular}{|c|c|c|}
\hline Item (in $\mathrm{g} \cdot \mathrm{kg}^{-1}$ silage DM intake) & FTS & DTS \\
\hline \multicolumn{3}{|l|}{ Starch } \\
\hline Intake & 344 & 284 \\
\hline Digested in the rumen & 247 & 259 \\
\hline Digested postruminally & 92 & 24 \\
\hline Digested in the total tract & 339 & 283 \\
\hline \multicolumn{3}{|l|}{ Dietary protein ${ }^{\mathrm{b}}$} \\
\hline Intake & 73 & 74 \\
\hline Digested in the rumen & 52 & 57 \\
\hline Digested postruminally & 17 & 12 \\
\hline Digested in the total tract & 69 & 69 \\
\hline Digestible true microbial protein & 70 & 61 \\
\hline Metabolisable protein & 87 & 73 \\
\hline
\end{tabular}

For abbreviations see Table I.

a The values presented in the table were calculated on the basis of the results from in vivo and in sacco experiments. Starch and protein digested postruminally was estimated from the difference between amounts digested in the total tract and those digested in the rumen. Digestible microbial true protein was estimated as the microbial protein yield $\times 0.75 \times 0.85$, AFRC $(1992)$.

$\mathrm{b}$ The values refer only to silage protein, urea supplement was not taken into account.

large enough to affect the proportions of VFA in the faeces (Tab. VIII).

Data on ruminal and postruminal starch digestion suggest that FTS support more glucogenic energy than DTS. An additional important source of glucogenic energy is propionic acid produced in the rumen and it seems that FTS may be beneficial also from this point of view. The molar proportion of non-glucogenic acetate and butyrate to glucogenic propionate tended to be higher in sheep which were given DTS than in sheep which were fed with FTS (Tab. V). Silages did not differ in concentrations of fermentation end-products (Tab. I) and therefore the differences are considered to be a result of fermentation in the rumen. Our results are in disagreement with data reported by $[12,14,20,22,37,40]$. In these trials, the acetate to propionate ratio in the rumen tended to decrease with the increased rate and extent of starch degradation in the rumen. Such disagreements may be due to the amount of starch digested in the rumen. In the above-mentioned studies the effect of degradation characteristics of starch was confounded with the higher amount of rumen degradable starch. However, in the present experiment, the diets differed only in the extent and rate of starch digestion (Tab. II) while the estimated amount of starch digested in the rumen was similar in both diets (Tab. IX). It seems that the characteristics of ruminal starch degradation per se turn the fermentation pattern in the rumen in the opposite direction to that of the amount of rumen degradable starch.

The results from the present experiment (Fig. 1) suggest that FTS may maintain ruminal $\mathrm{pH}$ at a higher level than DTS. The data were not consistent with the findings of Martin et al. [24] who observed no difference in ruminal $\mathrm{pH}$ value of steers given either flint or dent corn. In diets containing large amounts of maize silage, animal performance may be adversely affected by subacute rumen acidosis [10]. The possibility of manipulating rumen $\mathrm{pH}$ value by 
choosing an adequate genotype, is therefore of great practical importance. However, as already mentioned, the results concerning faeces composition (Tab. VIII) indicate that the maize genotype can also affect the intensity of fermentation in the large intestine. Žust et al. [51] reported that infusion of large amounts of maize-based concentrates into the caecum caused pronounced lactic acid production in the large intestine, resulting in acute ruminant lactic acidosis. From this point of view, dent type maize might have a comparative advantage.

\subsection{Digestion of non-grain parts of the maize plant}

The results regarding the degradation of non-grain parts (Tab. IV) suggest that the FTS diet offers better conditions for cellulolysis in the rumen than the DTS diet. The better conditions in a diet containing FTS were probably due mainly to a higher ruminal $\mathrm{pH}$ value. For optimal cellulose degradation, rumen $\mathrm{pH}$ should be maintained above 6.2 [18]. In the present experiment, the period during which the rumen $\mathrm{pH}$ was below the critical value was considerably longer in animals receiving DTS than in animals which were given FTS (Fig.1). A difference in digestion of non-grain parts of the maize plant in the rumen may also be a consequence of a direct negative effect of starch on the degradation of cell walls. Using an in vitro buffer system that can maintain $\mathrm{pH}$ at $5.8,6.2$ or 6.8 , Grant and Mertens [18] observed that the addition of maize starch accentuated the negative effect of low $\mathrm{pH}$ on fibre digestion. In practice, maize silage is usually combined with other feeds. In the case of a high roughage diet, the positive effect of FTS on the rumen environment may fail while in the case of high concentrate diet it may be accelerated.

Although the in sacco degradability of non-grain parts of flint hybrid in the rumen of sheep given the FTS diet was higher than the degradability of non-grain parts of the dent hybrid in the rumen of sheep which were given a DTS diet (Tab. IV), the whole tract digestibility of NDF and ADF was higher in DTS than in FTS (Tab. VI). The diet did not affect the fractional outflow rate (Tab. VI). Therefore, a higher digestibility of NDF and ADF in DTS could only be explained by the compensatory digestion of the fibre fraction in the large intestine. The observation that increased starch availability in the rumen may lead to a shift of NDF digestion from the rumen to the large intestine has already been reported [5, 24].

\subsection{Protein value of silages made from dent and flint type hybrids}

The results of the current study suggest that grain texture substantially affects the protein value of maize silage. FTS was characterised by lower ruminal protein degradability than DTS (Tab. III). Differences may be due to a different protein distribution of maize endosperm. A proportion of $(\alpha, \beta, \delta)$-zeins is reported to be higher in flint maize than in dent [38] and the latest $(\delta$-zein) is highly resistant to degradation in the rumen [19]. Lower protein degradability in FTS did not adversely affect true protein digestibility in the total tract (Tab. VI) and therefore the estimated amount of postruminally digested protein was about $40 \%$ higher in FTS than in DTS (Tab. IX). The results in regard to protein degradability are in agreement with the results of Babnik, Verbič, Michalet-Doreau and ŽnidaršičPongrac (unpublished results) who reported higher protein degradability for ensiled dent type maize grain in comparison to the ensiled flint type grain. Besides protein degradability, the type of hybrid also affected the synthesis of microbial protein in the rumen. The efficiency of microbial protein synthesis when expressed in relation to dry matter intake was about $15 \%$ higher in sheep given FTS than in sheep given DTS (Tab. VII). We believe that the probable reason for higher microbial protein yield in FTS was its beneficial effect on the rumen environment. Low rumen $\mathrm{pH}$ value, measured for the DTS diet, is expected to divert the available energy in 
the rumen to nongrowth functions, i.e. maintaining neutral $\mathrm{pH}$ in bacterial cells [43]. A tendency for a higher efficiency of microbial protein synthesis in flint type maize when compared to dent type has also been reported for dried grain [37]. As a result of lower protein degradability and higher microbial protein synthesis in the rumen, FTS had a higher concentration of metabolisable protein $\left(87 \mathrm{vs} .73 \mathrm{~g} \cdot \mathrm{kg}^{-1} \mathrm{DM}\right.$ intake, Tab. IX) and higher nitrogen retention (146 vs. $120 \mathrm{~g} \mathrm{~N}$ per $\mathrm{kg}$ of $\mathrm{N}$ intake, $P<0.05$; Tab. VII) than DTS. Extensive fermentation in the large intestine (Tab. VIII) is expected to increase faecal $\mathrm{N}$ excretion [33]. However, in the present experiment, faecal $\mathrm{N}$ excretion was similar among diets (Tab. VII) while urinary $\mathrm{N}$ excretion tended to be higher in DTS (Tab. VII). The most probable reason for lower urinary $\mathrm{N}$ excretion in FTS was a more balanced protein and energy supply for the growth of the microbial population in the rumen.

\section{CONCLUSIONS}

The results suggest that the type of maize grain (dent vs. flint) markedly affects the site of starch and protein digestion along the gastro-intestinal tract of sheep. In silage made from FTS, ruminal degradability of starch and protein was lower than in the silage made from DTS. Flint type hybrid silage enabled more favourable conditions for cellulolysis and more efficient microbial protein synthesis in the rumen than the dent type silage. As a result of lower protein degradability and higher microbial protein yield in the rumen, FTS provides about $20 \%$ more metabolisable protein than DTS.

\section{ACKNOWLEDGEMENTS}

Research was supported by the Slovenian Ministry of Higher Education, Science and Technology and by the Ministry of Agriculture, Forestry and Food.

\section{REFERENCES}

[1] AFRC, A reappraisal of the calcium and phosphorous requirements of sheep and cattle, Nutr. Abs. Rev. Ser. B 61 (1991) 573-612.

[2] ARC, The nutrient requirements of ruminant livestock, CAB, Slough, 1984.

[3] Argillier O., Barriere Y., Genotypic variation for digestibility and composition traits of forage maize and their changes during the growing season, Maydica 41 (1996) 279-285.

[4] Boehringer, Methods of enzymatic bioanalysis and food analysis, Boehringer, Mannheim, 1995.

[5] Callison S.L., Firkins J.L., Eastridge M.L., Hull B.L., Site of nutrient digestion by dairy cows fed corn of different particle sizes or steam-rolled, J. Dairy Sci. 84 (2001) 14581467.

[6] Chen X.B., Hovell F.D.DeB., Ørskov E.R., Brown D.S., Excretion of purine derivatives by ruminants: effect of exogenous nucleic acid supply on purine derivative excretion by sheep, Brit. J. Nutr. 63 (1990) 131-142.

[7] Chen X.B., Ørskov E.R., Hovell F.D.DeB., The use of intragastric infusion in studies on excretion of purine derivatives as a measure of microbial protein supply in ruminants, in: Eggum B.O., Boisen S., Børsting C., Danfær A., Hvelplund T. (Eds.), Protein metabolism and nutrition, Vol. 2, National Institute of Animal Nutrition, Foulum, 1991.

[8] Deinum B., Steg A., Hof G., Measurement and prediction of digestibility of forage maize in The Netherlands, Anim. Feed Sci. Technol. 10 (1983/84) 301-313.

[9] Dewar W.A., McDonald P., Determination of dry matter in silage by distillation with toluene, J. Sci. Food Agric. 12 (1961) 790-795.

[10] Dewhurst R.J., Wadhwa D., Borgida L.P., Fisher W.J., Rumen acid production from dairy feeds. 1. Effects on feed intake and milk production of dairy cows offered grass or corn silages, J. Dairy Sci. 84 (2001) 2721-2729.

[11] Diez M.T., Arin M.J., Resines J.A., Simultaneous determination of allantoin and creatinine in urine by a rapid reversed-phase liquid chromatographic method, J. Liq. Chromatogr. 15 (1992) 1337-1350.

[12] Doggett C.G., Hunt C.W., Andrae J.G., Pritchart G.T., Kezar W., Harrison J.H., Effect of hybrid and processing on digestive characteristics of corn silage, J. Anim. Sci. 76 (Suppl. 1) (1998) 196. 
[13] Durand M., Kawashima R., Influence of minerals in rumen microbial digestion, in: Ruckebusch Y., Thivend P. (Eds.), Digestive physiology and metabolism in ruminants, MTP Press Ltd., London, 1980, pp. 375-408.

[14] Ekinci C., Broderick G.A., Effect of processing high moisture ear corn on ruminal fermentation and milk yield, J. Dairy Sci. 80 (1997) 3298-3307.

[15] Fernandez I., Michalet-Doreau B., Starch and fibre distribution in maize silages in relation to particle size, J. Sci. Food Agric. 83 (2003) 147-150.

[16] Flachowsky G., Baldeweg P., Schein G., A note on the in sacco dry matter degradability of variously processed maize grains and of different maize varieties in sheep, Anim. Feed Sci. Technol. 39 (1992) 173-181.

[17] Goering H.K., Van Soest P.J., Forage fiber analyses, USDA Handbook No. 379, USDA, Washington, 1970.

[18] Grant R.J., Mertens D.R., Influence of buffer $\mathrm{pH}$ and raw corn starch addition on in vitro fiber digestion kinetics, J. Dairy Sci. 75 (1992) 2762-2768.

[19] Hancock K.R., Ealing P.M., White D.W.R., Identification of sulphur-rich proteins which resist rumen degradation and are hydrolysed rapidly by intestinal proteases, Brit. J. Nutr. 72 (1994) 855-863.

[20] Herrera-Saldana R., Gomez-Alarcon R., Torabi R., Huber J.T., Influence of synchronizing protein and starch degradation in the rumen on nutrient utilization and microbial protein synthesis, J. Dairy Sci. 73 (1990) 142-148.

[21] Holdeman L.V., Moore W.E.C., Anaerobe laboratory manual, V.P.I. Anaerobe Laboratory, Blackburg, 1975.

[22] Knowlton K.F., Glenn B.P., Erdman R.A., Performance, ruminal fermentation, and site of starch digestion in early lactation cows fed corn grain harvested and processed differently, J. Dairy Sci. 81 (1998) 1972-1984.

[23] Knowlton K.F., Dawson T.E., Glenn B.P., Huntington G.B., Erdman R.A., Glucose metabolism and milk yield of cows infused abomasally or ruminally with starch, J. Dairy Sci. 81 (1998) 3248-3258.

[24] Martin C., Philippeau C., Michalet-Doreau B., Effect of wheat and corn variety on fibre digestion in beef steers fed high-grain diets, J. Anim. Sci. 77 (1999) 2269-2278.

[25] Matthé A., Lebzien P., Flachowsky G., Influence of maize grain drying process on its in situ degradability in dairy cows, J. Anim. Feed Sci. 8 (1999) 379-386.
[26] Mills J.A.N., France J., Dijkstra J., A review of starch digestion in the lactating dairy cow and proposals for a mechanistic model: 1. Dietary starch characterisation and ruminal starch digestion, J. Anim. Feed Sci. 8 (1999) 291339.

[27] Mills J.A.N., France J., Dijkstra J., A review of starch digestion in the lactating dairy cow and proposals for a mechanistic model: 2. Postruminal starch digestion and small intestinal glucose absorption, J. Anim. Feed Sci. 8 (1999) 451-481.

[28] Moore J.A., Pond K.R., Poore M.H., Goodwin T.G., Influence of model and marker on digesta kinetic estimates for sheep, J. Anim. Sci. 70 (1992) 3528-3540.

[29] Naumann K., Bassler R., Die chemische Untersuchung von Futtermitteln. Methodenbuch, Band 3, Verlag Neumann, Neudamm, 1976.

[30] Nocek J.E., Tamminga S., Site of digestion of starch in the gastrointestinal tract of dairy cows and its effect on milk yield and composition, J. Dairy Sci. 74 (1991) 3598-3629.

[31] Owens F.N., Zinn R.A., Kim Y.K., Limits to starch digestion in the ruminant small intestine, J. Anim. Sci. 63 (1986) 1634-1648.

[32] Ørskov E.R., McDonald I., The estimation of protein degradability in the rumen from incubation measurements weighted according to rate of passage, J. Agric. Sci. 92 (1979) 499-503.

[33] Ørskov E.R., Fraser C., Mason V.C., Mann S.O., The influence of starch digestion in the large intestine of sheep on caecal fermentation, caecal microflora and faecal nitrogen excretion, Brit. J. Nutr. 24 (1970) 671-682.

[34] Ørskov E.R., Hovell F.D.DeB., Mould F., The use of nylon bag technique for the evaluation of feedstuffs, Trop. Anim. Prod. 5 (1980) 195-213.

[35] Philippeau C., Michalet-Doreau B., Influence of genotype and stage of maturity of maize on rate of ruminal starch degradation, Anim. Feed Sci. Technol. 68 (1997) 25-35.

[36] Philippeau C., Michalet-Doreau B., Influence of genotype and ensiling of corn grain on in situ degradation of starch in the rumen, J. Dairy Sci. 81 (1998) 2178-2184.

[37] Philippeau C., Martin C., Michalet-Doreau B., Influence of grain source on ruminal characteristics and rate, site and extent of digestion in beef steers, J. Anim. Sci. 77 (1999) 15871596.

[38] Philippeau C., Landry J., Michalet-Doreau B., Influence of the protein distribution of maize 
endosperm on ruminal starch degradability, $\mathrm{J}$. Sci. Food Agric. 80 (2000) 404-408.

[39] Rémond D., Cabrera-Estrada J.I., Champion M., Chauveau B., Coudure R., Poncet C., Effect of corn particle size on site and extent of starch digestion in lactating dairy cows, J. Dairy Sci. 87 (2004) 1389-1399.

[40] Schroeder J.W., Marx G.D., Park C.S., Waxy corn as a replacement for dent corn for lactating dairy cows, Anim. Feed Sci. Technol. 72 (1998) 111-120.

[41] STATGRAPHICS PLUS, Statistical Graphics Corp., Rockville, 1994

[42] SAS, SAS ${ }^{\circledR}$ User's Guide: Statistics, 8th ed., SAS Inst., Inc., Cary, NC, USA, 1999.

[43] Strobel H.J., Russell J.B., Effect of pH and energy spilling on bacterial protein synthesis by carbohydrate-limited cultures of mixed rumen bacteria, J. Dairy Sci. 69 (1986) 29412947.

[44] Tamminga S., Van Straalen W.M., Subnel A.P.J., Meijer R.G.M., Steg A., Wever C.J.G., Blok M.C., The Dutch protein evaluation system: the DVE, OEB-system, Livest. Prod. Sci. 40 (1994) 139-155.

[45] Theurer C.B., Huber J.T., Delgado-Elorduy A., Wanderley R., Invited review: Summary of steam-flaking corn or sorghum grain for lactating cows, J. Dairy Sci. 82 (1999) 1950_ 1959.

[46] Udén P., Colucci P.E., Van Soest P.J., Investigation of chromium, cerium and cobalt as markers in digesta. Rate of passage studies, J. Sci. Food Agric. 31 (1980) 625-632.

[47] Van Soest P.J., Nutritional ecology of the ruminant, Cornell University Press, Ithaca, 1994, 467

[48] Van Soest P.J., Robertson J.B., Lewis B.A., Methods for dietary fiber, and nonstarch polysaccharides in relation to animal nutrition, J. Dairy Sci. 74 (1991) 3583-3597.

[49] Verbič J., Stekar J.M.A., Resnik-Čepon M., Rumen degradation characteristics and fibre composition of various morphological parts of different maize hybrids and possible consequences for breeding, Anim. Feed Sci. Technol. 54 (1995) 133-148.

[50] Wilkinson J.M., Toivonen M.I., World silage. A survey of forage conservation around the world, Chalcombe Publications, Lincoln, 2003, 204 p.

[51] Žust J., Pestevšek U., Vengušt A., Einfluss der Milchsäuregärung im Dickdarm auf die akute Laktatacidose beim Rind, Dtsch. Tierärztl. Wschr. 107 (2000) 359-363. 